\title{
Study of The Effectiveness of Human Capital Investment
}

\author{
Fitri Nurmahmudah \\ Graduate School \\ Yogyakarta State University \\ Yogyakarta, Indonesia \\ fnurmahmudah@gmail.com \\ Lantip Diat Prasojo \\ Yogyakarta State University \\ Yogyakarta, Indonesia \\ lantip1975@gmail.com
}

\author{
Edison Ompe \\ Graduate School \\ Yogyakarta State University \\ Yogyakarta, Indonesia \\ edison_ompe@yahoo.co.id \\ Novri Pahrizal \\ Graduate School \\ Yogyakarta State University \\ pahrizal.novri@gmail.com
}

\begin{abstract}
The purpose of this research is to describe the empirical view and analyze how good influence of effectiveness of human capital investment and its impact to teachers' performance productivity from variable of academic degree, teaching skill , individual capability, and work motivation. The unit of human capital investment analysis and the respondents of this research are all teachers of SMK at Province Daerah Istimewa Yogyakarta. This research used path analysis approach to explain and describe the condition of each variable descriptively and to examine the relation of quality between research variables. Respondents of the research studied were that all teachers of SMK at DIY are 7,177 persons and they were taken a sample research by using Isaac \& Michael samples consist of 331 teachers from 29 SMK at DIY. The results show (1) there is any positive effect of education level (X1) and individual capability (X3) on human capital investment effectiveness (Y1); and there is no positive influence teaching skill (X2) and work motivation (X4) on human capital investment effectiveness; (2) there is no positive effect of academic degree (X1), teaching skill (X2), individual capability (X3), and work motivation (X4) on performance productivity (Y2); 3) there is any influence of academic degree (X1), teaching skill (X2), individual capability (X3), and work motivation (X4) toward effectiveness of human capital investment (Y1) directly and no influence in indirect; and (4) there is any influence of education level (X1), teaching skill (X2), individual ability (X3), and work motivation (X4) on work performance productivity directly and indirectly.
\end{abstract}

Keywords-academic degree, teaching skill, individual capability, work motivation, hci, performance productivity.

\section{INTRODUCTION}

The era of globalization is the world of education is required to have multiple roles, which must prepare a qualified human and comptenced related to the progress of science and technology, or humans who have mental readiness and skill readiness skills (professional) and education is capable of preparing a competent human.
Education has an important role in improving human resources. Education fully affects the nation's economic growth. This is not only because education will affect a productivity, but also affect the fertility (birth rate) of society. By education making human resources more quickly understands and ready faces changes in life. So, education is regarded as a human resources investment in general. Education contributes greatly to the development of socioeconomic life through the improvement of knowledge, capability, skills, attitudes and productivity.

In relation to costs and benefits, education can be viewed as one investment (human investment). In this case, the process of knowledge and skills through education is not a form of consumption alone, but it is an investment. It is also similar expressed by Mark Blaug (1976: 19)[1] which states that:

".... A good case can now be made for the view that educational expenditure does partake to a surprising degree of the nature of investment in enhanced future output. To that extent, the consquences of education in the sense of skills embodied in people may be viewed as human capital, which is not to say that people themselves are being treated capital. In other word, the maintenance and improvement of skills may be seen as investment in human beings, but the resources devoted to maintaining and increasing the stock of human beings remain consumption by virtue of the abolition of slavery".

In some previous researches, human capital investment has provided a deep understanding of improving the compatibility between performance, effectiveness and individual capability toward prosperity, improving skills and competence for each individual. Where Human Capital Investment (HCI) is defined as the effect of formal education on the level of economic growth, it means that the higher formal education obtained will increase the individual performance productivity in an 
organization or institution (in this case is SMK). This means similar with the theory of Human Capital Investment, that education has an effect on productivity improvement because education plays a role in improving capability, skills, and competencies that must be developed by a teacher. So that, that will appear new technology, new product, new process, and so on. Appearing of new and more useful thing will encourage the growth of the ability to participate in MEA.

Based on the above explanation, The purpose of this research is to describe the empirical view and analyze how good influence of effectiveness of human capital investment and its impact to teachers' performance productivity from variable of academic degree, skill, individual capability, and work motivation by using path analysis approach to explain and describe the condition of each variable in detail and to examine the relationship between the variables of research variables. The research findings are (1) there is any positive influence of academic degree $\left(\mathrm{X}_{1}\right)$ on the effectiveness of human capital investment $\left(\mathrm{Y}_{1}\right),(2)$ there is any positive effect of teaching skill $\left(\mathrm{X}_{2}\right)$ on effectiveness of human capital investment $\left(\mathrm{Y}_{1}\right),(3)$ there is any positive effect of individual capability $\left(\mathrm{X}_{3}\right)$ on the effectiveness of human capital investment $\left(\mathrm{Y}_{1}\right),(4)$ there is positive influence effect of work motivation $\left(\mathrm{X}_{4}\right)$ on the effectiveness of human capital investment $\left(Y_{1}\right),(5)$ there is any positive effect of academic degree $\left(\mathrm{X}_{1}\right)$ on performance productivity $\left(\mathrm{Y}_{2}\right),(6)$ there is any positive influence of teaching skill $\left(\mathrm{X}_{2}\right)$ on performance productivity $\left(\mathrm{Y}_{2}\right),(7)$ there is any positive influence of individual capability $\left(\mathrm{X}_{3}\right)$ on performance productivity $\left(\mathrm{Y}_{2}\right),(8)$ there is any positive influence of work motivation $\left(\mathrm{X}_{4}\right)$ on performance productivity $\left.\left(\mathrm{Y}_{2}\right), 9\right)$ there is an influence of education level $\left(\mathrm{X}_{1}\right)$, teaching skill $\left(\mathrm{X}_{2}\right)$, individual ability $\left(\mathrm{X}_{3}\right)$, and work motivation $\left(\mathrm{X}_{4}\right)$ on effectiveness of human capital investment $\left(\mathrm{Y}_{1}\right)$ directly and indirectly, and (10) there is an influence of education level $\left(\mathrm{X}_{1}\right)$, teaching skill $\left(\mathrm{X}_{2}\right)$, individual ability $\left(\mathrm{X}_{3}\right)$, and work motivation $\left(\mathrm{X}_{4}\right)$ on performance productivity $\left(\mathrm{Y}_{2}\right)$ directly and indirectly.

\section{LITERATURE}

\section{A. Academic Degrees}

In general Academic degree is closely related to preparing the teachers (educators) required by an institution by the purpose to prepare qualified educators. According to Andrew E. Sikula in Mangkunegara (2003: 50)[2] academic degree is a long-term process that uses a systematic and organized procedure, in which managerial labor learns conceptual and theoretical knowledge for general purposes.

\section{B. Teaching skill}

Teaching skills are essentially special abilities with regard to aspects of the implementation of learning activities whicimust be owned and applied by everyone who has a profession as a teacher, tutor, trainer or facilitator in carrying out learning. Pintrich \& Schunk (2002) $)^{[3]}$ illustrates six aspects of teacher's teaching skills. The six aspects are: (1) Reviewing previous learning, (2) Providing new materials, (3) Providing training, (4) Providing feedback, (5) Providing self-training, and (6) Reviewing the material Has been taught.

\section{Individual Capability}

According to Gibson (1997) in the book Manajemen Sumber Daya Manusia Lanjuttan by Sanusi Hamid (2014) ${ }^{[4]}$, the physical and mental capabilities for person to carry out a job. Snell (1992) in the book Manajemen Sumber Daya Manusia Lanjuttan by Sanusi Hamid (2014)[4] suggests that low-capability employees will use the time of greater effort than high-ability employees to complete a job. As an effort to improve performance productivity, employees to obtain high performance in addition to required change, which is no less important is to drive employees.

\section{Motivation}

Motivation has three elements that are closely related to each other, consisting of needs, encouragements and goals. Motivation is a term commonly used for all forms of desire, need, and security. Regarding the meaning of self-motivation there are various definitions, Stephen P. Robbins (1996) ${ }^{[5]}$ in his book Organizational Behavior defines motivation as: "The willingness to exert high levels of effort toward organizational goals, conditioned by efforts ability to satisfy some individual need".

\section{E. Human Capital Investment}

The concept of human capital investment that supports economic growth, has existed since the days of Smith (1776), Thunen (1875) and other classical theorists before the 19th century which emphasized the importance of human capital investment. Human capital is a stock of the productive abilities and knowledge that occur in society (Becker, 1975, pp. 334) ${ }^{[6]}$. Human capital is a long-term investment in human resource development to increase productivity. The importance of human capital is the existing knowledge on human resources is the driving base in increasing productivity. 


\section{F. Productivity}

Measuring productivity in the field of education is not an easy case because education is a non-profit sector that does not measure its output with profit or nominal money but by doing coaching on humans so to know the success rate takes a long time. Performance productivity is a mental attitude that always looking for improvements to what has been there (Sondang, 2009: 99) ${ }^{[7]}$. Such an attitude will encourage a person not to feel satisfied immediately but continue to develop themselves and improve the ability of work through continuous improvement.

\section{METHOD}

\section{A. Object}

The object of this research is 29 Vocation Senior High School (SMK) in Business and Management Subject in Province Daerah Istimewa Yogyakarta.

\section{B. Populasi dan Sampel}

The population used in this study is all teachers of SMK amounted to 7,177 teachrers, while the sample used in this study amounted to 331 teachers by using Isaac \& Michael samples (5\% significant level). Technique of selecting sample is by using puposive sampling.

\section{Instrument Test}

For validity test is by using confirmatory factor analysis which aims to confirm the dominant factors in a group of variables.

\section{Techniques of Analyzing Data}

Data analysis in this research used Path Analysis with the help of Lisrel 8.50.

\section{RESULTS}

Based on the above theoretical studies, the hypotheses for this research are:

$\mathrm{H}_{0}$ : There is no positive influence, direct and indirect of academic degree, teaching skill s, individual capability and work motivation towards the effectiveness of human capital investment and perfomance productivity.

$\mathrm{H}_{1}$ : There is any positive influence, direct and indirect of academic degree, teaching skill s, individual capability and work motivation towards the effectiveness of human capital investment and perfomance productivity.
The path diagram can be described as follows:

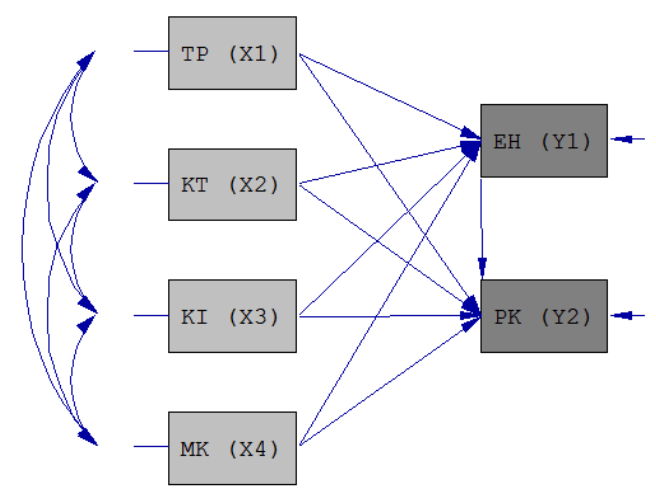

Fig. 1. Path Anlysis Model

\section{A. Model Fit Tesy}

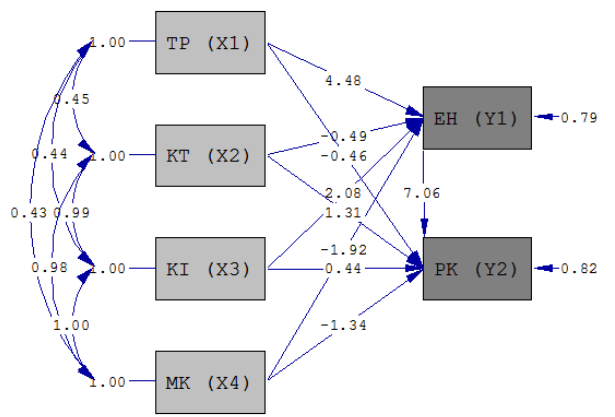

Chi-Square $=0.00, d f=0, P-$ value $=1.00000$, RMSEA $=0.000$

Fig. 2. Conformity Testing Model Figure

Based on the results above, the citeria of fit model was obtained Chi Square 0.00, df =0, RMSEA =0,000, and P-Value $=1.00000$. The value reaches a predefined standard where the value of Chi Square $0.00<1$, x df $=1$, RMSEA $<0,08$, and PValue $>0,05$. So it can be concluded that the data obtained in the field are match with the model built.

\section{B. Hypothesis Testing}

1) First hypothesis. There is any positive influence of academic degree $\left(\mathrm{X}_{1}\right)$ on the effectiveness of human capital investment $\left(\mathrm{Y}_{1}\right)$. 
From the calculation can be obtained coefficient coefficient $\mathrm{P}_{\mathrm{x} 1 \mathrm{y} 1}=0.24734$ with $\mathrm{t}_{\text {counted }}=4.48466$. The value on the $\mathrm{t}_{\text {table }}$ with the significance level of 0.05 and the number of respondents $(n)=331$ obtained $t_{\text {table }}=1.65251$ so $t_{\text {counted }}>t_{\text {table }}$, then it is rejected $\mathrm{H}_{0}$ and accepted $\mathrm{H}_{1}$. Thus, there is any positive influence of academic degree on the effectiveness of human capital investment.

2) Second hypothesis. There is any positive effect of teaching skill $\left(\mathrm{X}_{2}\right)$ on the effectiveness of human capital investment $\left(\mathrm{Y}_{1}\right)$.

From the calculation can be obtained coefficient coefficient $P_{x 2 y 1}=-0.17820$ with $t_{\text {count }}=-0.49285$. The value on the $t_{\text {table }}$ with the significance level of 0.05 and the number of respondents $(n)=331$ obtained $t_{\text {table }}=1.65251$ so $t_{\text {counted }}<t_{\text {table }}$, then it is rejected $\mathrm{H}_{1}$ and accept $\mathrm{H}_{0}$. Thus, there is no positive effect of teaching skill on the effectiveness of human capital investment.

3) Third hypothesis. There is a positive effect of individual capability $\left(\mathrm{X}_{3}\right)$ on the effectiveness of human capital investment $\left(\mathrm{Y}_{1}\right)$.

From the calculation can be obtained coefficient coefficient $\mathrm{P}_{\mathrm{x} 3 \mathrm{y} 1}=1.53799$ with $\mathrm{t}_{\text {counted }}=2.07681$. The value on the $\mathrm{t}_{\text {table }}$ with the significance level of 0.05 and the number of respondents $(n)=331$ obtained $t_{\text {table }}=1.65251$ so $t_{\text {counted }}>t_{\text {table }}$, then it is reject $\mathrm{H}_{0}$ and accepted $\mathrm{H}_{1}$. Thus there is influence of individual capability to effectiveness of human capital investment.

4) Fourth hypothesis. There is any positive influence of work motivation $\left(\mathrm{X}_{4}\right)$ to effectiveness of human capital investment $\left(\mathrm{Y}_{1}\right)$.

From the calculation can be obtained coefficient of $\mathrm{P}_{\mathrm{x} 4 \mathrm{y} 1}=$ -1.09102 with $t_{\text {counted }}=-1,91630$. The value on the $t_{\text {table }}$ with the significance level of 0.05 and the number of respondents $(\mathrm{n})=$ 331 obtained $t_{\text {table }}=1.65251$ so $t_{\text {counted }}<t_{\text {tabel }}$, then it is rejected $\mathrm{H}_{1}$ accept $\mathrm{H}_{0}$. Thus there is no positive effect of work motivation on the effectiveness of human capital investment.

5) Fifth hypothesis. There is a positive effect of academic degree $\left(\mathrm{X}_{1}\right)$ on performance productivity $\left(\mathrm{Y}_{2}\right)$.

From the calculation can be obtained coefficient coefficient $P_{x 1 y 2}=-0.026753$ with $t_{\text {counted }}=-0.46282$. The value on the $t_{\text {table }}$ with the significance level of 0.05 and the number of respondents $(n)=331$ obtained $t_{\text {table }}=1.65251$ so $t_{\text {counted }}<t_{\text {tabel }}$, then it is rejected $\mathrm{H}_{1}$ accept $\mathrm{H}_{0}$. Thus there is no positive effect of academic degree on performance productivity.

6) Sixth hypothesis. There is a positive effect of teaching skill $\left(\mathrm{X}_{2}\right)$ on performance productivity $\left(\mathrm{Y}_{2}\right)$.

From the calculation can be obtained coefficient coefficient Px2y $2=0.48073$ with $t_{\text {counted }}=1.30656$. The value on the $t_{\text {table }}$ with the significance level of 0.05 and the number of respondents $(n)=331$ obtained $t_{\text {table }}=1.65251$ so $t_{\text {counted }}<t_{\text {tabel }}$, then it is rejected $\mathrm{H}_{1}$ accept $\mathrm{H}_{0}$. Thus there is no positive effect of teaching skill on performance productivity.

7) Seventh hypothesis is that there is positive influence of individual capability $\left(\mathrm{X}_{3}\right)$ toward performance productivity $\left(\mathrm{Y}_{2}\right)$.

From the calculation can be obtained coefficient coefficient $\mathrm{P}_{\mathrm{x} 3 \mathrm{y} 2}=0.33243$ with $\mathrm{t}_{\text {counted }}=0.43841$. The value on the $\mathrm{t}_{\text {table }}$ with the significance level of 0.05 and the number of respondents $(n)=331$ obtained $t_{\text {table }}=1.65251$ so $t_{\text {counted }}<t_{\text {tabel }}$, then it is rejected $\mathrm{H}_{1}$ accept $\mathrm{H}_{0}$. Thus there is no positive effect of individual ability toward performance productivity.

8) Eighth hypothesis is that there is any positive influence of work motivation $\left(\mathrm{X}_{4}\right)$ to performance productivity $\left(\mathrm{Y}_{2}\right)$.

From the calculation can be obtained coefficient coefficient $P_{x 4 y 2}=-0,77914$ with $t_{\text {counted }}=-1.33783$. The value on the $t_{\text {table }}$ with the significance level of 0.05 and the number of respondents $(n)=331$ obtained $t_{\text {table }}=1.65251$ so $t_{\text {counted }}<t_{\text {tabel }}$, then it is rejected $\mathrm{H}_{1}$ accept $\mathrm{H}_{0}$ Thus there is no positive effect of work motivation toward performance productivity.

\section{Influences of Total Direct and Indirect.}

Obtained by direct and indirect influence between exogenous variables on endogenous variables. This can be seen in the following table.

TABLE.1. Influences of Total Direct and Indirect.

\begin{tabular}{|l|l|l|l|}
\hline \multirow{2}{*}{ Variable Effect } & \multicolumn{3}{c|}{ Influence/Effect } \\
\cline { 2 - 4 } & Direct & Indirect & Total \\
\hline X1-Y1 & 0.24734 & & 0.24734 \\
\hline X1-Y2 & 0.07164 & 0.09839 & 0.17003 \\
\hline X2-Y1 & -0.1782 & & -0.1782 \\
\hline X2-Y2 & 0.40984 & -0.07089 & 0.33895 \\
\hline
\end{tabular}


Table 1, Cont.

\begin{tabular}{|l|l|l|l|}
\hline $\mathbf{X 3 - Y 1}$ & 1.53799 & & 1.53799 \\
\hline $\mathbf{X 3 - Y 2}$ & 0.94425 & 0.61182 & 1.55607 \\
\hline $\mathbf{X 4 - Y 1}$ & -1.09102 & & -1.09102 \\
\hline $\mathbf{X 4 - Y 2}$ & -1.21315 & -0.43401 & -1.64716 \\
\hline $\mathbf{Y 1 - Y 2}$ & & & 0.3978 \\
\hline $\mathbf{X 1 , X 2 , X 3 , X 4 ~ - > ~ Y 1 ~}$ & $\mathbf{0 . 5 1 6 1 1}$ & $\mathbf{0}$ & $\mathbf{0 . 5 1 6 1 1}$ \\
\hline $\mathbf{X 1 , X 2 , X 3 , X 4 ~ - > ~ Y 2 ~}$ & $\mathbf{0 . 2 1 2 5 8}$ & $\mathbf{0 . 2 0 5 3 1}$ & $\mathbf{0 . 4 1 7 8 9}$ \\
\hline
\end{tabular}

Based on the above table, on ninth hypothesis that there is influence total of academic degree $\left(\mathrm{X}_{1}\right)$, teaching skill $\left(\mathrm{X}_{2}\right)$, individual capability $\left(\mathrm{X}_{3}\right)$, and work motivation $\left(\mathrm{X}_{4}\right)$ toward effectiveness of human capital investment $\left(\mathrm{Y}_{1}\right)$ is directly acceptable because P-Value counted $_{(\mathbf{0 , 5 1 6 1 1})}$ is larger than the standard P-Value $=0.05$ and there is no influence total in indrect. While for tenth hypothesis, there is that influence total of academic degree $\left(\mathrm{X}_{1}\right)$, teaching skill $\left(\mathrm{X}_{2}\right)$, individual capability $\left(\mathrm{X}_{3}\right)$, and work motivation $\left(\mathrm{X}_{4}\right)$ toward performance productivity $\left(\mathrm{Y}_{2}\right)$ in direct and indirect can be said accepted because $\mathrm{P}-\mathrm{V}$ alue $\mathrm{e}_{\text {counted }}$ in direct and inderict respectively $\mathbf{0 , 2 1 2 5 8}$ and $\mathbf{0 , 2 0 5 3 1}$ is larger than the standard $\mathrm{P}-$ Value $=0.05$.

\section{AKNOWLEDGEMENTS}

This article will be presented at The $1^{\text {st }}$ Yogyakarta International Conference on Educational Management/Administration and Pedagogy (YICEMAP 2017) in May 132017.

We would also like to show our gratitude for head of Education and Cultural Office of DI. Yogyakarta province and Headmasters of all Vocational Senior High School of DI. Yogyakarta province in giving a permission to conduct this research and then for all teachers of all Vocational Senior High School of DI. Yogyakarta province in helping us as respondent of this research.

\section{REFERENCES}

[1] Mark Blaug. "The Economics of Education: An Annotated Bibliography". 3d ed. Oxford: Pergamon Press. 1976. p. 19.

[2] Safri Mangkuorawira. "Manajemen Sumber Daya Manusia Strategik". Jakarta: Ghalia Indonesia. 2004. p.200.

[3] Paul R. Pintrich \& Dale H. Schunk. "Motivation in Education (Theory, Research, and Application)." New Jersey: Prentice-Hall, Inc. 2002.

[4] Sanusi Hamid. "Manaemen Sumber Daya Manusia Lanjutan". Yogyakarta: Deepublish. 2014. p. 95-96.

[5] Stephen P. Robbins. "Organizational Behavior Concept, Controversiest, Application”, Eaglewoods Cliffs, Prentice Hall Inc. 1996.
[6] Gary S. Becker. "Human capital: a theoritical approach and empirical analysis with special reference to education". New York: Columbia University Press. (1975). pp.334

[7] P. Siagian Sondang, "Organisasi, Kepemimpinan dan Perilaku Administrasi”. Jakarta: Gunung Agung. 2009. p.99. 